\title{
EL EPISCOPADO EN EL CONCILIO VATICANO II
}

DOI: https://doi.org/10.52039/seminarios.v59i208.254

MARIO MORONTA*

INTRODUCCIÓN

La conmemoración de los 50 años del inicio del Concilio Vaticano II resulta una buena oportunidad para reflexionar sobre este acontecimiento de gracia para la Iglesia. El Concilio es mucho más que una reunión de Obispos y todavía mucho más que la producción de un buen número de documentos. El acontecimiento conciliar es la expresión de una vida de Iglesia que osa revisarse y mirar hacia adelante con la confianza puesta en el Espíritu para renovarse y responder a los desafíos que el momento le estaba planteando.

En esta línea, el Vaticano II no fue un Concilio para condenar herejías ni para definiciones dogmáticas. Fue un encuentro eclesial de Obispos de todo el mundo que realizaron una revisión de vida, a la luz de la Palabra de Dios y de la Tradición viva de la misma Iglesia. Así, no sólo pudieron dar respuestas a interrogantes, sino adelantarse, en medio de un cambio de época, para insertarse en un mundo con el cual debe dialogar y al cual debe prestar su servicio de comunión, servicio y caridad.

Una lectura atenta, hoy, de los Documentos conciliares y todo lo que ellos supusieron en su elaboración, nos permite descubrir y profundizar el espíritu del mismo Concilio: el de la renovación, el diálogo y el compromiso con la humanidad. Desde esta perspectiva, nos vamos a encontrar con verdades teológicas que no se habían aclarado lo suficientemente, o habían sido puestas entre paréntesis, o que, sencillamente, no habían sido reflexionadas a lo largo de la historia.

Desde este horizonte, nos encontramos ciertamente con una realidad que va a marcar -y sigue marcando- tanto la reflexión como la acción pastoral post-conciliares. Se trata de la idea de sacramentalidad. La Iglesia es reconocida como el Sacramento de la comunión y la salvación (cf. LG 1; AG 1). Lejos de poner a un lado toda la teología de los sacramentos, le va a dar mayor fuerza. Hay una razón para ello: el reconocimiento de una Iglesia que es Sacramento de Jesucristo Salvador; quien, a la vez, es Sacramento del Padre y su designio de salvación.

Esto va a marcar algunos temas y también la invitación a una acción evangelizadora decidida en el mundo moderno, en el cual la Iglesia, con diálogo y servicio, anuncia el Evangelio de Jesús de Nazaret. Entre los varios temas nos

* Obispo de San Cristóbal de las Casas (Venezuela). 
vamos a encontrar el del Episcopado. Este va a ser visto como «sacramento», en la perspectiva de la sucesión apostólica y de la colegialidad episcopal. No va a constituirse como «otro» (un octavo) ni le va a quitar peso al sacramento del orden. Todo lo contrario, los Padres Conciliares van a poner el acento sobre la sacramentalidad del episcopado y así recuperar una dimensión olvidada por la misma Iglesia desde aproximadamente el siglo IV-V de nuestra era.

Lo que nos proponemos exponer en las páginas siguientes es lo que el Concilio Vaticano II nos indica acerca de la sacramentalidad del episcopado. Esto supone ver cuál fue el camino hasta llegar a él y, posteriormente, dejar abierta la cuestión acerca de la necesidad de un estudio mucho más profundo acerca de la Teología del Episcopado.

\section{Antes del Concilio Vaticano II}

\section{Desde los inicios}

Con la expansión del cristianismo «hasta los confines de la tierra», la Iglesia fue consolidando tanto su conciencia misionera como su organización. El elemento común que le dio consistencia fue el de la koinonía. Tanto en el Nuevo Testamento como en los Padres de la Iglesia, conseguimos las fuentes que nos permiten delinear dicha experiencia. Junto a la vivencia de la koinonía, encontramos la de la diakonía. Con ésta, a la vez, podemos entender cómo esa organización desde la comunión podía ser capaz de cumplir con la Misión recibida. Por eso, desde los mismos inicios de la Iglesia podemos y debemos hablar de ministerialidad. Ambas, comunión y ministerialidad, son inseparables. Hallan su centro y fuente en Cristo, que revela la comunión trinitaria y la comunión que también crea con la humanidad; además, aparece como el Servidor por excelencia cuando cumple la Misión recibida: hacer realidad el designio de salvación del Padre.

A partir del siglo I, se cuenta con un ordenamiento que permite ver a la Iglesia como comunión-servicio y ejecutora de la Misión evangelizadora. No fue tarea fácil. Poco a poco se fue caminando. Gracias al entusiasmo apostólico se le fue dando un rostro a la Iglesia en esa línea antes indicada. Elementos característicos de ese ordenamiento los hallamos en la fidelidad a la verdad y su conocimiento, importancia de la tradición apostólica y la acción externa y, ante todo, en una organización de ministerios para impulsar y promover la vida nueva en Cristo1.

En ese ordenamiento, comenzó a darse una episkopé, especie de comité de hombres, con frecuencia convocados para una tarea directiva. Entre ellos encontramos a Tito, Timoteo, Clemente Romano e Ignacio de Antioquía². «Estos 'varones probados', que recibieron de los apóstoles una especial función de

1. Cf. B. Dupuy, Teología de los ministerios, en Feiner-Löhrer (ed.), Mysterium Salutis. Manual de Teología como historia de la salvación, IV/2, Madrid 1975, 483.

2. Cf. Ibid. 
vigilancia en la Iglesia, ejercieron, sin duda, un influjo decisivo en la naciente tendencia hacia un episcopado monárquico. Imitan en todo al apóstol que les ha transmitido la fe; son sus hermanos espirituales y tienen que conservar lo que han recibido de él. Tienen que velar por el legado apostólico de la fe y organizar los ministerios de la Iglesia» ${ }^{3}$.

A partir de ellos y junto con ellos, los presbíteros y diáconos van cumpliendo su papel de administrar y guiar las comunidades cristianas. Los presbíteros, en comunión con el obispo, constituyen un presbyterium. Con fundamento en los escritos del Nuevo Testamento, se fue delineando el triple ministerio del obispo, del presbítero y del diácono, así como el llamado «episcopado monárquico», del cual encontramos referencias en las cartas de Ignacio de Antioquía. Según éste, el monoepiscopado formaría parte de la estructura de la Iglesia, y el obispo sería el presidente de una comunidad urbana. El presbiterio debía estar unido a él como las cuerdas de la lira para hacer sonar un solo coro armónico 4 .

Ireneo de Lyon hablará de «sucesión apostólica», que hace referencia a la tradición apostólica. Por otro lado, la traditio apostolica, atribuida a Hipólito, presenta una descripción de la ordenación episcopal, que se realiza con la imposición de las manos: así se ejerce la máxima dignidad episcopal. Con Hipólito comienza a denominarse al obispo con una terminología sacerdotal; lo cual fue asumido posteriormente por Cipriano de Cartago y, a partir de entonces, como algo habitual. El Episcopado tiene que ver con la celebración de la Eucaristía. Para Cipriano, el Episcopado es uno e indiviso y es ejercitado por los obispos en forma de comunión: el obispo está en la Iglesia y la Iglesia está en el obispo 5 .

Un elemento interesante es la consideración del obispo como testigo de la fe y de la Palabra. «Igual que la denominación 'obispo' se considera en orden a las funciones de dirección y de pastor en la vida intraeclesiástica, la denominación 'mártir' se desarrolla también como categoría independiente ('mártir' en cuanto participación en la pasión de Jesús, en los dones del Espíritu como testimonio de la pretensión de la Iglesia a la publicidad). Sin entrar en el origen de la denominación 'mártir', es decir, cómo el término se ciñó en sentido exclusivo para el testigo de la sangre, será suficiente hacer constar que el concepto tiene una valencia teológica propia ya en Ignacio, y probablemente también en los relatos recogidos por Clemente sobre la muerte de Pedro y Pablo» ${ }^{6}$.

3. Ibid.

4. Cf. W. Kasper, Chiesa Cattolica, Essenza-Realtà-Missione, Brescia 2012, 360 (versión cast.: Iglesia católica, Sígueme, Salamanca 2013). «Después de la caída de Roma y el final del episcopado de Santiago surge poco a poco en Oriente el episcopado monárquico. A finales del siglo I hay en la cristiandad dos estructuras jerárquicas: El Oriente ('antioqueño') conoce en todas partes el episcopado monárquico; el Occidente ('romano') tiene todavía colegios de presbíteros o presbíteros-obispos» (B. Dupuy, Teología de los ministerios, 484).

5. Cf. W. Kasper, Chiesa Cattolica, 361.

6. P. Dias, «La Iglesia en la Escritura y en el siglo Il», en M. Schmauss - A. Grillmeier - L. Scheffczyk, Historia de los Dogmas, III, cuaderno 3a-b, Madrid 1978, 149. 
Sin embargo, la distinción entre obispo y presbítero no era clara en los primeros tiempos de la Iglesia, y ambas realidades llegaron hasta confundirse. San Jerónimo tuvo argumentos contra la sacramentalidad del episcopado y prefirió la igualdad potestativa-sacramental entre ambos, para lo cual se apoya en textos del Nuevo Testamento donde ambos conceptos no se hallan diferenciados. Según Jerónimo, se trataba de lo mismo: obispos y presbíteros tenían las mismas funciones, excepto la ordenación; la distinción entre ambos no sería por disposición divina, sino por una simple costumbre eclesiástica ${ }^{7}$.

Durante el Medioevo, hubo una mayor difusión del cristianismo en áreas rurales y las comunidades que iban surgiendo eran asignadas a presbíteros. Estos, que antes habían vivido la experiencia de los presbíteros en torno a un obispo, se convirtieron en presidentes de las comunidades y de las celebraciones eucarísticas bajo la autoridad del obispo. Se concibió el ministerio presbiteral como más sacerdotal ${ }^{8}$. En esta línea era comprensible que la doctrina jeronimiana se prolongara en la edad media (y posteriormente). «Pero aquí se refuerza con el establecimiento de la relación del sacramento del orden con la eucaristía como criterio decisivo» ${ }^{9}$

Lombardo destacará la excelencia del presbiterado y del diaconado que habrían sido los únicos que se dieron en la Iglesia primitiva y que responderían al mandato apostólico. El episcopado no tendría una dimensión sacramental, sino que formaría parte de las dignidades y oficios. Santo Tomás afirmará que existen tres órdenes (obispo-presbítero-diácono) relacionados de manera peculiar con la eucaristía. Santo Tomás le niega al episcopado toda condición de carácter sacramental ${ }^{10}$. Sin embargo, el Aquinate hizo una reflexión que permitió ver la diferencia existente entre el obispo y el presbítero. Los presbíteros se equiparan a los obispos en cuanto al Corpus Christi verum presente en la eucaristía, que ambos pueden realizar. A los obispos les corresponde una potestad mayor en lo que respecta al Corpus Christi mysticum de la Iglesia, potestad de la que hace parte el ser ministro de la ordenación; por tanto, un poder sacramental. Dicho poder supera el campo puramente jurisdiccional. Esta visión y lo que ella encierra no fue tomada en cuenta y, más bien, la dimensión jurisdiccional se hizo más autónoma ${ }^{11}$.

Siglos más tarde, el Concilio de Trento tampoco resolverá la situación sobre la sacramentalidad del episcopado. Congar advierte que si bien «este concilio debía responder a la Reforma, no ha tratado el problema eclesiológico » ${ }^{12}$. Trento reacciona, en esta materia unida a la del ministerio sacerdotal, contra lo que pro-

7. Cf. S. del Cura Elena, «Episcopado», en AA.VV., Diccionario del Sacerdocio, Madrid 2005, 239-240.

8. Cf. W. Kasper, Chiesa Cattolica, 363.

9. S. del Cura Elena, Episcopado, 240.

10. Cf. Ibid., 240-241.

11. Cf. W. Kasper, Chiesa cattolica, 364.

12. Y. Congar, Eclesiología. Desde San Agustín hasta nuestro días, en M. Schmaus - A. Grillmeier - L. Scheffczyk, Historia de los Dogmas, III, cuaderno 3c-d, Madrid 1976, 226. 
pone Lutero y los reformadores. En este sentido, el Concilio de Trento se basó más bien en la concepción medieval y definió el ministerio sacerdotal a partir de la potestad eucarística. Aquí incluyó lo referente al episcopado. El Concilio condenó la posición protestante que consideraba la ordenación sacerdotal como una invención humana. Trento habló de la institución por Jesús y del carácter indeleble que recibía el ordenado.

Sin embargo, el mismo Concilio de Trento habla de un ordenamiento jerárquico, en el cual los obispos están, en su cualidad de sucesores de los apóstoles, en un puesto superior a los presbíteros. No se define si esto es de naturaleza sacramental o jurídica, pero se puede ver el inicio de un cambio de orientación en la teología del ministerio episcopal. El mismo Concilio, a la vez, abrió una puerta interesante, al delinear un modelo pastoral del obispo y del presbítero, que apuntaba a la cura animarum, la cual, junto con la celebración eucarística, incluía la predicación, la administración de los sacramentos y la atención a los pobres. Algunos obispos se presentaron como ejemplo de ello: Roberto Belarmino, Francisco de Sales, entre otros ${ }^{13}$.

A esto se añade el hecho de que en la época post-tridentina quedan resabios del ordenamiento político-feudal de la Iglesia y de los obispos. Esta forma feudal del ministerio episcopal terminó con la revolución francesa y con el final de la Iglesia de Estado, al comienzo del siglo XIX. En esta nueva situación, nos rencontramos con el Concilio Vaticano I que, si bien se había propuesto aclarar la cuestión eclesiológica, por su prematura interrupción pudo tratar sólo el tema del Primado y la infalibilidad del obispo de Roma y no el ministerio episcopal ${ }^{14}$.

\section{El siglo de la Iglesia}

Prácticamente se puede catalogar el siglo XX como el siglo de la Iglesia. La reacción contra el modernismo obligó a un planteamiento directo sobre la teología de la Iglesia (eclesiología). Desde un punto de vista metodológico, se fue insistiendo en ir a las fuentes de la teología. «La renovación de los estudios bíblicos y patrísticos, que adquirieron su amplitud un poco más tarde, abrió en el mismo sentido la comprensión del misterio de la Iglesia como plenitud dentro del esquema del designio de Dios o de la historia de la salvación, es decir, de una historia en continuidad con la historia de Israel, centrada en Cristo, finalizada por su consumación escatológica» ${ }^{15}$. Comienza a darse un cambio de mentalidad eclesiológica y el final de la llamada «era constantiniana». En este horizonte, se habla de la Iglesia como «Cuerpo místico» y «Pueblo de Dios»; y se deja de

13. Cf. W. Kasper, Chiesa cattolica, 367-368.

14. Cf. Ibid., 368-369. Por otra parte, la clarificación de la teología del episcopado será una de las peticiones más formuladas y presentadas en la preparación y realización del Concilio Vaticano II. Cf. ibid., 369. El Vaticano I «no ha definido el origen ni de la jurisdicción de los obispos ni de la infalibilidad del Cuerpo episcopal». Y. Congar, Eclesiología, 281.

15. Ibid., 289-290. 
considerar la eclesiología como «jerarcología». Además, comienza a darse una apertura al laicado y se llega a hablar de «participación en el apostolado jerárquico» (Pío XI) en la perspectiva del sacerdocio común de los fieles bautizados. Pío XII, con Mystici corporis, subraya la relación de la Iglesia con Jesucristo; aunque no ocultaba una tendencia a absolutizar la institución jerárquica, la encíclica ponía a la Iglesia bajo el actualismo de la acción de Cristo ${ }^{16}$.

La reflexión teológica sobre la Iglesia, entendida como «Cuerpo de Cristo» y «Pueblo de Dios», va a permitir tres cosas esenciales: Un cambio de visión, apoyado en las fuentes y centrado en Cristo, con lo que se le abren las puertas a la «sacramentalidad» de la misma desde la consideración de Cristo, cual Sacramento del Padre. Entonces, se le podrá ver como cooperadora de la obra de la salvación. A la vez, considerando su organicidad, se la verá en su ministerialidad. Asimismo se hará memoria, desde su papel de cooperadora de la salvación, del mandato evangelizador, de modo que se la perciba también desde el horizonte de la Misión. Muchos teólogos apelarán al concepto de koinonía-comunión.

Hay dos elementos que no podemos obviar en la reflexión teológica previa al Concilio Vaticano II: uno de ellos es recurrente desde tiempos antiguos, y es el de la relación del episcopado con el primado. Otro, gracias a los estudios bíblicos, patrísticos y litúrgicos, es el tema del sacerdocio común de los fieles. En cuanto al primero, «el primado del obispo de Roma constituye una peculiaridad de la Iglesia Católica. Es la expresión visible de la unidad que caracteriza a la Iglesia de Jesucristo, garantía de la comunión entre las Iglesias y centro de la colegialidad episcopal. Es, en este sentido, un órgano ministerial constitutivo de la Iglesia, enraizado en la voluntad de Jesucristo y por ello irrenunciable en la autoconciencia y en la articulación eclesial» ${ }^{17}$. La función del obispo de Roma, se basa en la relación de la función que el Señor le entregara a Pedro. Esta función fue ejercida y reconocida en la Iglesia primitiva. La sede de Roma vino después que la primacía de Jerusalén se fue viniendo a menos, de modo que llegó a significarse así la llegada del tiempo de las naciones, antes de que la Iglesia vuelva a retornar a Jerusalén para el regreso del Señor ${ }^{18}$.

A lo largo de los siglos, siempre hubo una tensión teológica en torno al tema del primado, sobre todo en relación con el episcopado. Esto llegó a su culmen en Lutero, quien llegó a acusar al Papa de «anticristo». Para los reformadores protestantes, este asunto significó que el Papa oprimía el evangelio de Jesucristo. La vehemente polémica de los reformadores indujo a la teología pos-tridentina a poner de relieve el primado ${ }^{19}$. Así, la estrecha vinculación al Papa llegó a convertirse en un rasgo identificador del catolicismo ${ }^{20}$.

16. Ibid., 293.296.

17. E. Bueno de la Fuente, Primado, en AA.VV., Diccionario del Sacerdocio, Madrid 2005, 640.

18. Cf. B. Dupuy, Teología de los ministerios, 487-488.

19. Cf. W. Kasper, Chiesa cattolica, 406.408.

20. Cf. E. Bueno de la Fuente, Primado, 642. 
A esto se unió la presencia de fuerzas disgregadoras del poder papal. Tanto fuerzas de carácter político como influencias de carácter teológico pretendieron debilitar la autoridad de la Iglesia, por lo que fueron arreciando ataques contra el Papado. Siglos después, llegó el Vaticano I. «Frente a los gérmenes disolventes de la identidad eclesial, los Padres conciliares definieron solemnemente el carácter primacial del ministerio petrino como primado de jurisdicción universal». El origen está en el llamado de Jesús a Pedro, y no puede ser considerado como un elemento externo. No se trata sólo de un primado de honor, sino que es un verdadero primado de jurisdicción que fue otorgado a Pedro y que se prolonga en sus sucesores. Con esto, el Papa queda constituido como principio y fundamento visible de la unidad de la Iglesia. Esta propuesta no coloca al Papa al margen de la comunión eclesial, ni lo hace un «superobispo» en desmedro de la potestad de los obispos. «La definición del Vaticano I fue presentada de tal modo que no pudiera ser confundida o ejercida como desvalorización o descrédito de la autoridad episcopal (...). El Papa, en cuanto portador del ministerio petrino, puede ejercer su tarea propia respecto a cada una de las Iglesias, pero no como obispo de cada Iglesia concreta, sino en cuanto pastor supremo que tiene la responsabilidad de la unidad y de la comunión del cuerpo de las Iglesias ${ }^{21}$. El Concilio rechazará la idea de que los obispos serían meros funcionarios del $\mathrm{Papa}^{22}$.

El asunto de la infalibilidad del Papa estuvo siempre vinculado al estudio del Primado. Conviene observar, lo subraya Kasper, que el Concilio habla del magisterio infalible del Papa; que, de acuerdo a la tradición de Oriente y de Occidente, se trata de un carisma presente en el primado apostólico ${ }^{23}$.

Los acontecimientos históricos del momento adelantaron una clausura imprevista del Concilio Vaticano I. «Es de lamentar especialmente que no se pudiera estudiar el tema del episcopado, y consiguientemente una presentación más armónica y global de la doctrina eclesiológica» ${ }^{24}$. El tema del episcopado quedó como asignatura pendiente. Prevaleció nuevamente la concepción teológica descrita anteriormente.

En el siglo de la Iglesia, concretamente en el período pre-Vaticano II, el aporte de no pocos teólogos enriqueció la discusión sobre la relación entre el episcopado y el primado. Un ejemplo de ello lo encontramos en Karl Rahner y Josef Ratzinger, quienes abordan el tema de manera directa ${ }^{25}$.

Por lo que se refiere al segundo elemento, permitirá ir situando la teología del episcopado en el ámbito de la sacramentalidad. Al igual que el presbítero, el obispo, por el bautismo, es miembro del pueblo sacerdotal que es la Iglesia. De

21. Ibid., 643.

22. Cf. W. Kasper, Chiesa cattolica, 409.

23. Cf. Ibid., 410-411.

24. E. Bueno de la Fuente, Primado, 643-644.

25. K. Rahner - J. Ratzinger, Episkopat und Primat, Freiburg i.Br. 1961; versión cast.: Episcopado y Primado, Barcelona 1965 y ${ }^{2} 2005$. 
en medio de él son elegidos para el servicio sacerdotal de sus hermanos. Hay una razón clara: Cristo configura a Sí al pueblo de Dios y le da una dimensión sacerdotal. Todo brota del único Sacerdocio de Cristo. Quienes son elegidos y «ungidos» con el sacramento del orden sacerdotal son configurados de modo sacramental para actuar in persona Christi capitis a favor del Pueblo de Dios y en orden a la salvación de la humanidad.

También antes del Concilio Vaticano II, podemos encontrar algunos autores que han tratado acerca de la teología del Episcopado, con lo que fueron abonando el terreno para lo que el Vaticano II enfrentaría de manera clara y decidida ${ }^{26}$.

\section{En el Concilio Vaticano II}

\section{Preparación inmediata}

Trento no resolvió el problema de la sacramentalidad del episcopado. Ello propició que se mantuviera la tradición jeronimiana de igualdad potestativa-sacramental con el presbiterado y la propuesta tomista de la potestas conficiendi eucharistiam. Con todo, «Trento estuvo a punto de proclamar, en sus inicios, que los obispos han sido instituidos por Cristo iure divino y que, por esto, son superiores a los presbíteros (sacerdotes) y que, en consecuencia, toda su potestas proviene directamente de Cristo. Se pretendía hacer esta declaración como respuesta a la negación, por parte de los protestantes, de la institución divina del episcopado. Pero el concilio no llegó a aprobar esta doctrina, con lo cual permanecieron irresueltas en el ámbito doctrinal todas las tensiones teológicas y eclesiológicas implicadas en el debate ${ }^{27}$. La discusión o reflexión que se hace sobre el episcopado cual ius divinum tiene que ver también con la relación primado y episcopado ${ }^{28}$.

Poco a poco se fue profundizando en esta cualidad del episcopado como ius divinum. Así encontramos que Rahner y Ratzinger hablan de esto mismo en tér-

26. Cf. P. Anciaux, L'Épiscopat dans l'Église. Réflexions sur le ministère sacerdotal, Paris 1963; N. López Martínez, La distinción entre obispos y presbíteros: Burgense 4 (1963) 145-225; C. Pozo, Tres concepciones posibles del sacramento del orden. A propósito de la sacramentalidad del episcopado: Revista española de Teología 24 (1964) 127-135; AA.VV., L'Épiscopat et l'Église universelle Paris 1962; AA.VV. Teología del Episcopado (XXII Semana Española de Teología), Madrid 1963.

27. S. del Cura Elena, "La sacramentalidad del ministerio episcopal: sentido, implicaciones y recepción de la doctrina del Vaticano Ilı, en Facultad de Teología del Norte de España, Teología del Sacerdocio, El Ministerio Episcopal XXIV, Burgos 2001, 21.

28. Indica muy bien K. Rahner: «El papa -y el papa solo- posee, según doctrina católica definida, el pleno, inmediato, ordinario y universal primado episcopal de jurisdicción sobre la Iglesia entera y sobre cada uno de sus miembros y partes incluidos los obispos (DS 1831; $\mathrm{CIC}$, can. 218). Por otra parte, es doctrina católica inequívoca, aunque no se haya concretado todavía con la misma claridad en una definición que también el episcopado es iuris divini de tal forma (DS 960, 966, 1821, 1828), que el papa, pese a su primado de jurisdicción, no puede abolir el episcopado, que los obispos no se pueden considerar como meros funcionarios y vicarios del romano pontífice» (Episkopat, 71-73). 
minos bien interesantes: «Si hay la existencia de un episcopado iuris divini, hay también una esencia de un episcopado iuris divini» ${ }^{29}$. Con ello, en la práctica se abren las puertas a un posterior reconocimiento de la sacramentalidad del episcopado: «Surge de nuevo, y de manera apremiante, la cuestión de cuál será el contenido de esta potestad episcopal de jurisdicción del episcopado iuris divini, que el papa por principio no puede conservar para sí mismo» ${ }^{30}$.

El ius divinum arranca de la esencia de la Iglesia universal y de la esencia del episcopado considerado como colegio. La esencia de la Iglesia es siempre el fundamento de los poderes directivos en ella; y el episcopado visto en su conjunto (colegio) ayudará a resolver el ius divinum de cada Obispo ${ }^{31}$. Por eso, el mismo Rahner hablará «sobre la naturaleza teológica del colegio apostólico»" ${ }^{32} y$ del «colegio episcopal como sucesor del colegio apostólico» ${ }^{33}$.

Después de la convocatoria del Concilio Vaticano II por parte de Juan XXIII, fue constituida la Comisión ante-preparatoria, presidida por el Card. Tardini. Entonces, comenzó la importante tarea de recoger las sugerencias, propuestas y estudios, a modo de consulta para preparar los esquemas y temas conciliares. Uno de los temas que más se repetirán es el de la constitución jerárquica de la Iglesia, con énfasis en el episcopado. Las respuestas que llegaron de parte de los Obispos de todo el mundo coincidían en la solicitud de reflexionar sobre la doctrina de la constitución jerárquica de la Iglesia en la línea de Trento y Vaticano I: que debería dedicarse un tratamiento particular sobre los obispos, quienes, junto con el papa, son la continuación del colegio apostólico instituido por Cristo. A la vez, se pedía afirmar el origen divino del episcopado, su sacramentalidad y la colegialidad episcopal ${ }^{34}$.

Por su parte, las Congregaciones Romanas también van a insistir sobre la constitución jerárquica de la Iglesia. La Congregación Consistorial propone que el episcopado es un verdadero y propio sacramento; el episcopado monárquico es de origen divino, y que la forma de gobierno querida por Cristo en la Iglesia es «colegial». Por tanto el gobierno de la Iglesia universal corresponde al colegio de los obispos solo praeeunte S. Pontifice. Estos y otros puntos deberían definirse dogmáticamente. Otras Congregaciones no están de acuerdo con nuevas definiciones de carácter dogmático ${ }^{35}$. Podemos destacar que las Universidades y Facultades consultadas volvieron sobre el tema de la constitución jerárquica de la Iglesia, la colegialidad y la sacramentalidad del episcopado, el cual constituye la plenitud del sacramento del orden ${ }^{36}$.

29. Ibid., 75 .

30. Ibid., 77.

31. Cf. Ibid., 78-79.

32. Cf. Ibid., 81-90.

33. Cf. Ibid., 90-117.

34. Cf. U. Betti, La Dottrina sull'Episcopato del Concilio Vaticano II, Roma 1986, 19-20.

35. Cf. Ibid., 20-23.

36. Cf. Ibid., 23-25. 
Con estas indicaciones, una Comisión preparó el esquema sobre la Iglesia que sería presentado a los Padres Conciliares, en el cual había cuatro apartados que se referían al episcopado; éstos fueron preparados por una sub-comisión presidida por el Card. Ottaviani y que debía haber tenido en consideración el resultado de las consultas previas. En este sentido, se ofreció el siguiente orden: El episcopado como sacramento distinto del presbiterado; la potestad de los obispos; el magisterio eclesiástico; el derecho y deber de la Iglesia de predicar a todos el Evangelio ${ }^{37}$.

\section{La Discusión Conciliar}

El 23 de noviembre de 1962 fue presentado a los Padres Conciliares el EsQUEMA I DE ECCLESIA, en el que se habla de la sacramentalidad del episcopado, pero aún sin que se pueda deducir claramente una teología del episcopado. Se hacía referencia a que era la cima del sacerdocio o grado preeminente; pero se seguía viendo el episcopado como un peldaño ulterior suplementario del sacerdocio básico y fundamental, el presbiterado representativo ${ }^{38}$. Por otra parte, el texto fue muy criticado por los Padres Conciliares. Esto obligó a redactar el ESQUEMA II (abril-julio 1965).

Paulatinamente, se fue asumiendo en la discusión conciliar una perspectiva eclesiológica mucho más amplia. Así, se comenzó a ver a la Iglesia como un sujeto de fe y como un testimonio vivo de la fe proclamada. El Vaticano II fue presentando a la Iglesia como comunidad de quienes conocen y siguen a Jesús. De este modo, fue introduciéndose la categoría de pueblo de Dios como la más adecuada para hablar de la Iglesia. Con ésta, se aclaran, se articulan y se asumen las otras categorías: Iglesia-comunión, Cuerpo, Sacramentos, misterio. Además, con esta categoría de Pueblo de Dios se fue a las raíces bíblicas y se acentuó la igualdad fundamental dentro de la Iglesia, el aspecto comunitario y orgánico y la ministerialidad dentro de ella ${ }^{39}$.

Desde esta perspectiva, por lo que se refiere al Episcopado, según lo recuerda Kasper, el Vaticano II termina obrando un cambio copernicano respecto a la tradición medieval, y se mete en las raíces y la tradición de la Iglesia primitiva, para definir el ministerio episcopal como plenitud del sacramento del orden, y el ministerio sacerdotal (presbiteral) como participación gradual en el único orden. Así, se repropone la concepción sacramental del episcopado de los primeros siglos de la Iglesia y se concibe al Obispo como sucesor de los Apóstoles. Por la ordenación, el Obispo va a recibir el triple oficio de sacerdote, maestro y pastor. Esto significa que la ordenación episcopal transmite, en línea de principio, la

37. Cf. Ibid., 30.

38. Cf. S. del Cura Elena, La sacramentalidad, 27.

39. Cf. G. Zanchi, Alcuni momenti cruciali del Vaticano II, en AA.VV. Teologia del Vaticano II, Milano 2012, 33-34. 
jurisdicción, presente e incluida en la potestad del pastor, aunque ésta tenga necesidad de asignación a una diócesis, o en casos excepcionales, a tareas muy importantes. A la vez, se mira el episcopado como colegio, en comunión con el Papa. Aquellas tres funciones antes mencionadas sólo pueden ser ejercidas en la comunión jerárquica con el papa y con los miembros del colegio episcopal. De aquí se deducirán consecuencias prácticas y pastorales que serán asumidas inicialmente y sobre todo en el Decreto Christus Dominus ${ }^{40}$.

La discusión eclesiológica y, en particular, sobre la teología del episcopado ocupó un amplio espacio de tiempo: hubo confrontaciones que obligaron a cambiar esquemas y a promover grupos de trabajo. Al final, se impuso el consenso de la comunión que culminó con la Lumen gentium. Allí, además de encontrar una teología de la Iglesia, conseguimos las bases para la reflexión teológica sobre el episcopado, tema que nos interesa en este momento ${ }^{41}$. Esta apretadísima visión, hasta ahora presentada, nos permitirá introducirnos en lo que el Concilio Vaticano II nos presenta sobre el Obispo (episcopado).

\section{Teología del Episcopado a partir del Concilio Vaticano II}

Lo que el Concilio Vaticano II nos dice sobre los Obispos (y por ende sobre el Episcopado) lo encontramos eminentemente en Lumen gentium, y en el Decreto Christus Dominus, sin dejar a un lado menciones importantes en otros documentos. Después de una presentación general, en especial de lo que dice la Lumen gentium, propondremos una síntesis de la teología del Episcopado organizada en algunos bloques, con el fin de tener una mejor visión de conjunto de la misma. Esto nos permitirá buscar los fundamentos que sustentan y explican la teología del Episcopado en el Vaticano II.

\section{Líneas generales}

Nos limitaremos a enunciar lo que Lumen gentium propone acerca del Episcopado. Los números 18-27 del Capítulo III hacen referencia de manera directa al Episcopado (los n. 28-29, hablarán del Presbiterado y del Diaconado). Este Capítulo III lleva por título «Constitución jerárquica de la Iglesia y particularmente del Episcopado». Como bien lo explicita el título, va a presentarse de una manera particular lo referente a los Obispos. Es interesante comprobar que en el

40. Cf. W. Kasper, Chiesa catolica, 369-370.

41. Recomiendo para un estudio y conocimiento más profundo sobre la discusión acerca del episcopado en la realización del Concilio: U. Betti, La Dottrina sull'episcopato del Concilio Vaticano II. II capitolo III della Costituzione dommatica Lumen Gentium, Roma, 1983; M. Faggioli, II Vescovo e il Concilio. Modello episcopale e aggiornamento al Vaticano II, Bologna 2005; J. Famere, Vescovi e diocesi, en G. Alberigo (ed.), Storia del Concilio Vaticano II, III, Bologna, 1998; versión cast. Salamanca 2006; A. Melloni, L'inizio del secondo periodo e il grande dibattito eclesiológico, en G. Alberigo (ed.), Storia del Concilio Vaticano II, III, Bologna 1998. 
capítulo II habla de «El pueblo de Dios». A él pertenecen quienes constituyen la jerarquía de la Iglesia (capítulo III), los laicos (capítulo IV) y los religiosos (capítulo VI) (Llama la atención que el capítulo V, sobre «la universal vocación a la santidad en la Iglesia», venga inmediatamente después de los laicos). Luego seguirá «La índole escatológica de la Iglesia peregrinante y su unión con la Iglesia celestial» (capítulo VII). Al finalizar, se habla de «la Santísima Virgen María, Madre de Dios, en el misterio de la Iglesia» (capítulo VIII) El inicio de Lumen gentium (capítulo I) nos presenta «el Misterio de la Iglesia».

En una primera lectura y visión global observamos que el Misterio de la Iglesia se hace patente en el Pueblo de Dios, compuesto por bautizados, llamados a la santidad (jerarquía, laicos y religiosos) y en camino hacia la plenitud escatológica. Los miembros de la Iglesia son miembros del pueblo sacerdotal y ejercen el sacerdocio común de los fieles identificados a Cristo Salvador (cf. LG 11). A la vez, ese Pueblo de Dios tiene un carácter misionero con el compromiso de anunciar el Evangelio y cooperar en la obra de la Redención; por eso es «sacramento universal de salvación» (AG 1). Y lo hace, enraizándose en la Trinidad Santa, en íntima unidad de sus miembros para lo cual también convoca a toda la humanidad, por lo que, además, es «Sacramento de comunión» (LG 1).

Este es el marco de referencia de la doctrina sobre el Episcopado en el Concilio Vaticano II. Al introducirnos en ella, no hemos de perder de vista lo anterior. En primer lugar, porque el episcopado (como el presbiterado y el diaconado) no es algo aislado o aparte del resto del Pueblo de Dios; en segundo lugar, porque la comprensión de dicha doctrina puede y debe partir de ese marco de referencia.

Para una mejor apreciación de lo que el Vaticano II dice sobre el Episcopado y así poder hacer una síntesis teológica, presentamos ahora los enunciados donde Lumen gentium habla del Episcopado.

Proemio (n. 18).

La Institución de los Doce (n. 19).

Los obispos, sucesores de los Apóstoles (n. 20).

El Episcopado como sacramento (n. 21).

El Colegio de los obispos y su Cabeza (n. 22).

Relaciones de los obispos dentro del Colegio (n. 23).

El Ministerio de los obispos (n. 24).

El oficio de los obispos de enseñar (n. 25).

El oficio de los obispos de santificar (n. 26).

El oficio de los obispos de regir (n. 27).

Por su parte, el Decreto Christus Dominus, sobre el Ministerio Pastoral de los obispos, sigue el siguiente íter:

-Proemio (nn. 1-3)

-Cap. I: Los obispos con relación a toda la Iglesia.

1. Papel que desempeñan los obispos en la Iglesia Universal (nn. 4-7).

2. Los obispos y la Sede Apostólica (nn. 8-10). 
-Cap. II: Los obispos en sus Iglesias particulares o diócesis.

1. Los obispos diocesanos (nn. 11-21).

2. Circunscripción de las diócesis (nn. 22-24).

3. Cooperadores del obispo diocesano en su cargo pastoral (nn. 25 y 35).

-Cap. III: Cooperación de los obispos al bien común de la Iglesia.

1. Sínodos, Concilios y, en especial, las Conferencias Episcopales (nn. 36-38).

2. Circunscripción de las Provincias Eclesiásticas y erección de regiones eclesiásticas. (nn. 39-41).

-Disposición general (n. 40).

Habida cuenta de lo antes señalado y en vistas a la presentación, a continuación, de una propuesta de síntesis teológica, queremos invitar al lector a que lea con atención y detenimiento los textos antes indicados que nos hablan precisamente de la doctrina del Episcopado en el Vaticano II.

\section{A modo de síntesis}

A continuación, vamos a proponer cinco bloques, a manera de síntesis, de la teología del Episcopado en el Concilio Vaticano II. En cada bloque, presentaremos de manera sintética lo que dice el Concilio y luego haremos algunas reflexiones a partir de la enseñanza conciliar.

\section{a) La sucesión apostólica}

Este apartado debe comenzar por una afirmación que aparece en el n. 18: «En orden a apacentar al Pueblo de Dios y acrecentarlo siempre, Cristo Señor instituyó en su Iglesia diversos ministerios dirigidos al bien de todo el Cuerpo... Este Santo Concilio, siguiendo las huellas del Vaticano I, enseña y declara, a una con él, que Jesucristo, Pastor eterno, edificó la santa Iglesia enviando a sus Apóstoles como Él mismo había sido enviado por el Padre (cf. Jn 20, 21) y quiso que sus sucesores, es decir, los Obispos, fuesen en la Iglesia los pastores hasta la consumación de los siglos». Los obispos, pues, son «Sucesores de los Apóstoles», instituidos por Cristo. A la vez, colocó al frente de ellos a Pedro. El Concilio «se propone, ante la faz de todos, profesar y declarar la doctrina de los Obispos, sucesores de los Apóstoles, los cuales, junto con el Sucesor de Pedro, Vicario de Cristo y Cabeza visible de toda la Iglesia, rigen la casa del Dios vivo».

Después de hablar de la institución de los Doce Apóstoles por parte de Jesús (n. 19), LG 20 trata directamente sobre la sucesión apostólica: «así como permanece el oficio concedido a Pedro, primero entre los Apóstoles, así también permanece el oficio de los Apóstoles de apacentar la Iglesia que permanentemente ejercita el orden sacro de los Obispos. En señal, pues, este sagrado Sínodo que los Obispos han sucedido por institución divina en el lugar de los Apóstoles, como pastores de la Iglesia y quien a ellos escucha, a Cristo escucha, y quien los desprecia, a Cristo desprecia y a Aquél que le envió» (cf. Lc 10, 16). En Christus 
Dominus, 1 , se vuelve a enfatizar esta idea: «Pero también los Obispos puestos por el Espíritu Santo, suceden a los Apóstoles en su misión de pastores de almas, y juntamente con el Sumo Pontífice, y bajo su autoridad, han sido enviados para perpetuar la obra de Cristo, Pastor eterno».

En el tema de la sucesión apostólica encontramos «una presencia peculiar de Cristo en los Obispos. Están llamados a actuar en nombre de Cristo y por la acción del Espíritu Santo recibido en la ordenación episcopal. La acción del Espíritu Santo va a marcar la dimensión carismática del ministerio de cada Obispo, pues queda habilitado para el ejercicio del ministerio apostólico» ${ }^{42}$. Ya, en lo antes indicado, se ve reflejada la sacramentalidad del episcopado. En Hch 20, 28 tenemos la descripción de la forma como se fue gestando y asumiendo la sucesión apostólica: «Les encomendaron que cuidaran de todo el rebaño en el que el Espíritu Santo les había puesto para ser pastores de la Iglesia de Dios».

Al hablar en el n. 20 de que quien escucha a los obispos, sucesores de los apóstoles, a Cristo escucha, además de introducir también la dimensión sacramental del episcopado, se manifiesta, con palabras evangélicas, la comunión de ministerio con Cristo, en cuyo nombre actúan los Apóstoles y sus Sucesores ${ }^{43}$. Por otro lado, en el Concilio «con su enseñanza acerca de la sucesión apostólica por institución divina, Lumen gentium establece que la comunión ministerial apostólica, participación solidaria de la potestad salvífico-comunitaria de Cristo, se perpetúa «en la comunión ministerial a través del tiempo, como una comunión a la vez sincrónica y diacrónica en la historia. Esa continuidad de comunión en el sacerdocio de Cristo permite que tenga valor perenne para el episcopado todo lo que de orden permanente en la Iglesia Cristo instituyó en el Colegio apostólico» ${ }^{44}$. Esa expresión comunional es comprensible, porque la Iglesia es un «sacramento de comunión», lo cual nutre sin duda la realidad sacramental del episcopado.

El misterio de comunión de la Iglesia se hace sentir en la historia y adquiere una expresión de sucesión. «La necesidad de una comunión sucesiva ministerial surge de la exigencia, en el plano ordenado de Dios, de su función para la comunión sucesiva eclesial en su totalidad $»^{45}$. La sucesión apostólica, entonces, va a ser una garantía de la presencia actuante de Cristo en la Iglesia, de la cual los obispos son pastores.

\section{b) Sacramentalidad del Episcopado}

Lumen gentium, 21 habla directamente sobre este tema. Para el cumplimiento de sus funciones ministeriales, al igual que los Apóstoles, los bispos han sido «enriquecidos por Cristo con la efusión especial del Espíritu Santo». La sacra-

42. Cf. S. del Cura Elena, Episcopado, 239.

43. Cf. A. Ruiz Freites, Colegio y comunión. El Colegio de los Obispos en su relación con la Iglesia como comunión, Roma 2001, 44.

44. Ibid.

45. Ibid., 45. 
mentalidad del Episcopado nos habla de la plenitud del sacerdocio que recibe todo obispo. «Este santo Sínodo enseña que con la consagración episcopal se confiere la plenitud del Sacramento del orden que por esto se llama en la liturgia de la Iglesia y en el testimonio de los Santos Padres 'supremo sacerdocio' o 'cumbre del ministerio sagrado'». Esta dimensión sacramental no se queda en una expresión litúrgico-ritual, sino que se realiza una transformación de carácter ontológico en la persona del obispo: «Es cosa clara que con la imposición de las manos se confiere la gracia del Espíritu Santo y se imprime el sagrado carácter, de tal manera que los obispos en forma eminente y visible hagan las veces de Cristo, Maestro, Pastor y Pontífice, y obren en su nombre».

Esto hace que todo el servicio ministerial (con sus tres oficios de santificar, enseñar y regir) esté impregnado de ese dinamismo sacramental propio del episcopado. Christus Dominus, 1, hace referencia a lo antes señalado: «Los obispos han sido constituidos por el Espíritu Santo, que se les ha dado, verdaderos y auténticos maestros de la fe, pontífices y pastores». Los números 3 y 4 del Decreto mencionan explícitamente la «consagración episcopal».

El tema de la sacramentalidad del episcopado fue altamente sugerido en las respuestas a las consultas pre-conciliares e intensamente debatido en el Vaticano II. Recordemos que, a lo largo de los siglos, la doctrina de la sacramentalidad del episcopado no se presentaba con claridad. Más bien se pensó en una equiparación sacramental entre el obispo y el presbítero: tanto el obispo como el presbítero tienen la potestad de «hacer la eucaristía» (conficiendi eucharistiam). Lo que hacía superior al episcopado era su capacidad de ordenar presbíteros y obispos.

Fruto de la discusión conciliar es lo que aparece plasmado en Lumen gentium, 21: la sacramentalidad del episcopado, considerado como «plenitudo sacramenti ordinis». La presentación de la Iglesia como sacramento (de comunión y salvación), aporte propio del Vaticano II, permitirá también considerar la sacramentalidad del episcopado ${ }^{46}$. «La sacramentalidad de la Iglesia significa que lo visible en ella constituye el signo eficaz y presencializador (símbolo real) de la salvación de Dios en Cristo para el mundo entero ${ }^{4}{ }^{4}$. Es éste el horizonte que nos permite considerar al episcopado domo una realidad sacramental: «Los obispos ejercen un ministerio sacramental inserto en la sacramentalidad de la Iglesia, como manifestación particular de la inserción de todos los ministerios en el interior de un pueblo de bautizados (cf. PO 9), para su edificación y su sustento. Pero la inclusión es mutua, pues, según una fórmula de San Cipriano recogida por Lumen gentium 23, 'el obispo está en la Iglesia y la Iglesia en el obispo'» ${ }^{48}$.

No se olvide tampoco que la Iglesia es «sacramento universal de salvación» (AG 1). El ministerio episcopal, con los otros tres oficios que le son propios,

46. Cf. S. del Cura Elena, La sacramentalidad, 43-44.

47. Ibid., 46.

48. Ibid., 47. 
apuntan a manifestar la Iglesia como tal. Así, «la sacramentalidad del episcopado es el fundamento real intrínseco del Colegio en la comunión salvífica, a través de los 'oficios' que confiere. Es también el fundamento real intrínseco de la comunión en el ministerio salvífico con Cristo y entre sí» ${ }^{49}$.

Como ya se indicó, al hablar de sacramentalidad del episcopado se incluye la «plenitud del sacramento del orden»; $y$ ha de ser considerado como tal no como un grado añadido que viene a completar lo ya alcanzado en el presbiterado ${ }^{50}$. Hay una dimensión nueva: con el episcopado se da la incorporación al pleno sacerdocio de Cristo y al Colegio. Hay una clara referencia a la colegialidad. «Es una gracia, comunión en la vida divina, en cuanto esa vida divina promueve el ejercicio, en la comunión de intención eficaz y salvífica, bajo la moción del Espíritu Santo, del sumo y pleno sacerdocio, en todo lo que esto implica como colegialidad y potencialidad y exigencia de determinación de misión canónica en la comunión jerárquica. La gracia sacramental del episcopado corresponde al carácter y a su impronta colegial ${ }^{51}$. Con esto, además, podemos ver la índole sacramental del Colegio episcopal, expresión de comunión ministerial: «El sacramento del orden en su plenitud, el episcopado, es visto así también como sacramento de la sucesión apostólica, constitutivo de esa comunión ministerial en cuanto sucesiva o diacrónica» ${ }^{52}$.

Desde esta perspectiva, podemos encontrar otra explicación para profundizar en la plenitud del sacerdocio en el episcopado y es su referencia a la actuación sacramental in nomine Ecclesiae. Es cierto que también los presbíteros lo hacen, pero «lo peculiar del obispo, ausente en el presbítero, sería esa capacidad que le es propia, en razón de la 'plenitud' del sacramento del orden, para representar a la entera Iglesia local o particular en la comunión completa de todas las Iglesias, dada su pertenencia al Colegio episcopal» ${ }^{53}$. Entonces, «la 'plenitud' del episcopado podría entenderse, por tanto, en esta dirección: la de ser representante visible de la Iglesia local o particular, que es comunidad eucarística, constituyendo sacramentalmente el lazo de unión con el resto del Colegio episcopal y con el Obispo de Roma y siendo garante de la unidad en la diversidad. Esta representación eclesial del obispo es inseparable de la configuración con Cristo para actuar in persona Christi y del ejercicio concreto de las potestades ministeriales» ${ }^{54}$.

49. A. Ruiz Freites, Colegio y comunión, 52.

50. Cf. S. del Cura Elena, La sacramentalidad, 48. «Pero el concilio no ha precisado ulteriormente cómo entender esa 'plenitud', en qué sentido, con qué tipo de implicaciones y de consecuencias, sobre todo para el conjunto del ministerio ordenado. Es ésta una tarea abierta a la reflexión teológica, en la que no puede descartarse el riesgo de explicar el alcance de la 'plenitud' reintroduciendo un tipo de discurso que LG 21 parece haber descartado (el de los grados progresivos que terminan haciendo del episcopado un complemento del presbiterado» (ibid., 48-49).

51. A. Ruiz Freites, Colegio y comunión, 54-55.

52. Ibid., 55.

53. S. del Cura Elena, Episcopado, 244.

54. Ibid. 
Aunque hablaremos de ellos luego, también puede verse la dimensión sacramental en los oficios que debe ejercer el obispo. «La sacramentalidad del episcopado y el otorgamiento sacramental de los tres 'munera' aparecen en los textos de Lumen gentium como dos afirmaciones estrechamente relacionadas entre sí» ${ }^{55}$.

\section{c) El Colegio Episcopal}

Al establecer los fundamentos del Colegio Episcopal, Lumen gentium, en el n. 22 dice: «Así como por disposición del Señor, San Pedro y los demás Apóstoles forman un solo Colegio Apostólico, de modo semejante se unen entre sí el Romano Pontífice, sucesor de Pedro, y los obispos, sucesores de los Apóstoles. Ya la más antigua disciplina, conforme a la cual los obispos establecidos por todo el mundo comunicaban entre sí y con el Obispo de Roma con el vínculo de la unidad, de la caridad y de la paz como también los concilios convocados para resolver las cosas más importantes, después de haber considerado el parecer de muchos, manifiestan la naturaleza y forma colegial propia del orden episcopal».

Indica Lumen gentium que el rito de ordenación donde los obispos asistentes imponen las manos sobre el candidato elegido tipifica la colegialidad episcopal. «Uno es constituido miembro del cuerpo episcopal en virtud de la consagración sacramental y de la comunión jerárquica con la Cabeza y miembros del Colegio». Es esencial la comunión con la Cabeza -el Romano Pontífice- para que el Colegio tenga autoridad. Por su parte, «el orden de los obispos, que sucede en el magisterio y en el régimen pastoral al colegio apostólico, junto con su Cabeza, el Romano Pontífice, y nunca sin esta Cabeza, es también sujeto de la suprema y plena potestad sobre la universal Iglesia, potestad que no puede ejercitarse sino con el consentimiento del Romano Pontífice».

El Colegio episcopal, además de expresar la variedad y la universalidad del Pueblo de Dios, es signo de unidad de la grey de Cristo. Por eso mismo, «los obispos gozan de su potestad propia en bien no sólo de sus fieles, sino incluso de toda la Iglesia, cuya estructura orgánica y cuya concordia es el Espíritu Santo». Christus Dominus, en su número 6, desarrolla más esta idea cuando habla de la solicitud de los obispos por todas las Iglesias. «Los obispos, como legítimos sucesores de los Apóstoles y miembros del Colegio Episcopal, tengan siempre conciencia de su unidad, y muestren su solicitud por todas las Iglesias, ya que por institución de Dios y exigencias del ministerio apostólico cada uno debe ser responsable de la Iglesia juntamente con los demás obispos». Esta preocupación se dirige de manera especial hacia aquellas regiones donde aún no se ha anunciado el Evangelio y donde los fieles están en peligro de apartarse de la vida cristiana e incluso de perder la fe. Christus Dominus, 7 hablará de la caridad eficaz con los obispos perseguidos.

55. Id., La sacramentalidad, 61. 
Como expresiones concretas de colegialidad se enumeran: el Concilio Ecuménico (LG 22), el Sínodo de obispos (ChD 5), acciones colegiales convocadas por el Papa (LG 22). Asimismo, «la unidad colegial se manifiesta en las mutuas relaciones de cada obispo con las Iglesias particulares y con la Iglesia universal. El Romano Pontífice, como sucesor de Pedro, es el principio y el fundamento perpetuo y visible de unidad así de los obispos como de la multitud de los fieles. Del mismo modo, cada obispo es el principio y fundamento visible de unidad en su propia Iglesia formada a imagen de la Iglesia universal; y así, en todas las Iglesias particulares y de todas ellas resulta la Iglesia católica una y única. Por esto cada obispo representa a su Iglesia, pero todos ellos a una con el Papa, representan toda la Iglesia en el vínculo de la paz, del amor y de la unidad» (LG 23). En esta línea, además de la solicitud por todas las Iglesias, los obispos deben promover y defender la unidad de la fe y la disciplina común, la justicia y la evangelización. Todos los obispos deben colaborar con el Romano Pontífice en el gran oficio de propagar la religión cristiana y prestar ayuda a las Iglesias más necesitadas.

¿Qué es la colegialidad? La Nota explicativa previa (n. 1) al Capítulo III de LG propuesta por la Comisión Doctrinal del Concilio nos dice lo siguiente: «El término Colegio no se entiende en un sentido estrictamente jurídico, es decir, de una asamblea de iguales que confieran su propio poder a quien los preside, sino de una asamblea estable, cuya estructura y autoridad deben deducirse de la Revelación. Por este motivo, en la respuesta al Modo 12 se dice explícitamente de los Doce [Apóstoles] que el Señor los constituyó a modo de colegio o grupo estable (...). Por la misma razón, se aplican también con frecuencia al Colegio de los obispos las palabras Orden o Cuerpo».

Así las cosas, la colegialidad es una propiedad esencial que afecta a la forma y la naturaleza del episcopado, «por la cual todos los obispos en unión inseparable con el Papa, constituyen juntos un cuerpo, un orden, una unidad, cuya función hace relación directa a la responsabilidad solidaria de la Iglesia universal y a la misión evangelizadora ${ }^{56}$. EI Vaticano II no ha inventado esta verdad eclesiológica, pero sí la ha actualizado ${ }^{57}$. En esta misma línea nos encontramos que la colegialidad tiene su origen y base en la sucesión apostólica (LG 22a), presenta una constitución interna que incluye la relación de los obispos con el Papa y viceversa (LG 22b) y alude al ejercicio concreto de la potestad colegial (LG 22c) ${ }^{58}$.

La colegialidad hay que verla desde el prisma de la eclesiología de comunión; así es como podemos ver «la consagración como causa, propiamente sacramental, la comunión jerárquica como condición indispensable» ${ }^{59}$. Esa comunión jerárquica «comprende por tanto en su fundamento la realidad ontológica de una

56. J. L. Cabria, Colegialidad y estructuras colegiales, en AA.VV., Diccionario del Sacerdocio, Madrid 2005, 114.

57. Cf. Ibid., 115.

58. Cf. Ibid., 116.

59. A. Ruiz Freites, Colegio y comunión, 60. 
comunión como participación del ministerio sagrado» ${ }^{60}$. A partir de esto, podríamos hablar de «comunión sacramental» entre los obispos, como lo sugieren los Lineamenta para la Asamblea General del Sínodo sobre la vida y ministerio de los Obispos (n. 5), que también resaltan una nueva figura del obispo de acuerdo con la eclesiología de comunión. Como realidad sacramental, el ministerio episcopal (y la colegialidad) se integra en una Iglesia comunión y misión ${ }^{61}$.

Nos pueden ayudar algunas ideas expresadas por el Cardenal Ratzinger en una conferencia pronunciada en Lima en 1986: «'Ordo', 'collegium'... en el contexto del servicio divino, significan la misma cosa: 'El obispo no es obispo a solas, sino que lo es únicamente en la comunión católica con aquellos que lo fueron antes que él, que lo son con él y que lo serán después de él. De esta manera la dimensión del tiempo está también comprendida en este término: la Iglesia no es algo que hacemos hoy, sino que lo recibimos de la misma historia de los creyentes y la transmitimos a otros como algo incompleto que solamente se realizará plenamente con el regreso del Señor. El Concilio, en una síntesis orgánica, fundió esta idea con la de la sucesión apostólica, que es un concepto fundamental de la ordenación episcopal. recuerda que también los Apóstoles era comunidad. Antes de obtener el nombre de Apóstoles figuran con el título de los Doce' (...). La 'colegialidad' pertenece a la esencia del ministerio episcopal; se vive y se realiza solamente en el 'estar juntos' de aquellos que representan, al mismo tiempo, la unidad del nuevo Pueblo de Dios» ${ }^{62}$.

Habida cuenta de todo esto, podemos recordar algunos modos de ejercer la colegialidad episcopal: Ios Concilios Ecuménicos, Sínodo de los obispos, Conferencias Episcopales (que expresan el espíritu colegial), la Curia Romana, las Visitas Ad Limina, los Concilios y Sínodos Provinciales (y nacionales).

\section{d) El ministerio de los obispos}

Lumen gentium pone como marco de referencia para hablar del ministerio episcopal la misión que Jesús entrega a sus Apóstoles y sucesores (n. 24) Más aún, es un mandato misionero presentado como un ministerio: «Este encargo que el Señor confió a los pastores de su pueblo es un verdadero servicio y en la Sagrada Escritura se llama muy significativamente 'diaconía', o sea, ministerio (cf. Hch 1, 17.25; Rom 11, 13; 1 Tim 1, 12)». Para la realización de su ministerio, «los obispos deben dedicarse a su labor apostólica como testigos de Cristo ante los hombres, no sólo interesándose por los que ya siguen al Príncipe de los Pastores, sino consagrándose totalmente a los que de cualquier modo perdieron el camino

60. Ibid., 61. Sobre la comunión jerárquica se puede consultar: G. Ghirlanda, Hierarchica Communio. Significato della formula nella Lumen gentium, Roma 1980.

61. Cf. S. del Cura Elena, La sacramentalidad, 72.

62. J. Ratzinger, La Eclesiología de/ Vaticano II: L'Osservatore Romano (ed. española) 32 (10.8.1986) 2.11; citado por L. E. Henríquez Jiménez, Constitución dogmática sobre la Iglesia (Lumen gentium), Caracas 1987, 41-42. 
de la verdad o desconocen el Evangelio o la misericordia salvadora de Cristo, hasta que todos caminen en toda bondad, justicia y verdad (Ef 5, 9)» (ChD 11).

Por la ordenación episcopal, los obispos reciben tres oficios que deben cumplir decididamente: ENSEÑAR-SANTIFICAR-REGIR. El de ENSEÑAR lo realizan como «pregoneros de la fe» y porque son maestros auténticos que hacen nuevos discípulos y predican al Pueblo de Dios la Palabra de salvación. Además, animan a la práctica de esa Palabra y vigilan para apartar la grey de todo error. Son testigos de la verdad divina y católica. Poseen el carisma del magisterio. Por el vínculo de la unidad con el Papa, asumen con sentido de comunión y obediencia su magisterio auténtico, aun cuando no hable ex cathedra (LG 25). En este mismo número se habla del tema de la infalibilidad del Papa «cuando proclama como definitiva la doctrina de fe o de costumbres». Esa infalibilidad «reside también en el Cuerpo de los obispos cuando ejercen el supremo magisterio universal juntamente con el sucesor de Pedro». Christus Dominus,12, también habla del oficio de enseñar y lo hace de manera explícita. Los números 13 y 14 hacen referencia directa a la catequesis, que debe constituir una de las preocupaciones más urgidas para todo obispo.

Al hablar del oficio de SANTIFICAR, Lumen gentium, 26 dice que «el obispo, revestido de la plenitud del Orden es el 'administrador de la gracia del supremo sacerdocio', sobre todo en la Eucaristía que él mismo ofrece, ya sea por sí, ya sea por otros, y por la que la Iglesia vive y crece continuamente». El ejemplo y testimonio de vida santa es clave en el ejercicio de este oficio: «los obispos, orando y trabajando por el pueblo, difunden de muchas maneras y abundantemente la plenitud de la santidad de Cristo». En la celebración de los sacramentos santifican a los fieles. Es un compromiso serio: «Ellos, finalmente, deben edificar a sus súbditos con el ejemplo de su vida y guardando su conducta no sólo de todo mal, sino con la ayuda del Señor, transformándola en bien dentro de lo posible para así, juntamente con la grey que se les ha confiado, llegar a la vida eterna». Christus Dominus, 15 asume y explicita lo referente a este oficio, y añade una recomendación: «En cuanto santificadores, procuren los obispos promover la santidad de sus clérigos, de sus religiosos y seglares, según la vocación peculiar de cada uno, sintiéndose obligados a dar ejemplo de santidad con la caridad, humildad y sencillez de vida. Santifiquen las Iglesias encomendadas a ellos, de forma que en ellas se advierta el sentir de toda la Iglesia de Cristo».

Christus Dominus, 16 habla del deber de REGIR Y APACENTAR que tienen los obispos y que deben realizar como quienes sirven y cuales pastores buenos que conocen su grey y son conocidos por ella. Para eso, además de la debida preocupación por todos, deben poseer «un tenor de vida que responda a las necesidades de su tiempo». Una especial dedicación la han de dirigir hacia sus sacerdotes, sus «próvidos cooperadores» (LG 28): hacia ellos, deben manifestar una preocupación integral que abrace desde lo espiritual hasta su sustento material y alto nivel académico. Por otra parte, también han de manifestar un 
serio interés por el bien de todos sus fieles y hacia los hermanos separados. Para ello, es preciso que estimulen las diversas formas de apostolado (ChD 17). En el ejercicio de esta función, que es también un deber, actúan como «vicarios de Cristo en las Iglesias que se les han encomendado» (LG 27), así podrán «edificar su grey en la verdad y la santidad». Lumen gentium precisa el sentido de este oficio: «Esta potestad que personalmente poseen en nombre de Cristo, es propia, ordinaria e inmediata, aunque el ejercicio de la misma, en último término, sea regulado por la autoridad suprema, y aunque, con miras a la utilidad de la Iglesia, pueda quedar circunscrita dentro de ciertos límites». Como consecuencia de ello tienen «el sagrado derecho y ante Dios el deber de legislar sobre sus súbditos, de juzgarlos y de regular todo cuanto pertenece al culto y organización del apostolado». Todo esto lo deben realizar como pastores a imagen de Cristo, Pastor Bueno. Ello conlleva dialogar con los suyos, cuidar de ellos «con la oración, con la predicación y con todas las obras de caridad», sin olvidar la atención por aquellos que no son de la única grey. Han de ser, igualmente, animadores de la dimensión misionera de todos sus fieles.

No se trata de oficios como si se tratara de funciones profesionales. Tienen una connotación sacramental por ser recibidos en la consagración episcopal, y que forman parte de la identidad propia del obispo. Estos munera encuentran así su fuente en la sacramentalidad del episcopado. Todo esto, a su vez, se realiza en la comunión jerárquica del colegio episcopal y llega a ser condición (no causa) de la transmisión de un poder que tiene origen sacramental ${ }^{63}$.

Para profundizar mejor sobre esto último es necesario ver la dimensión carismática de dichos munera. Por la acción del Espíritu Santo el obispo es consagrado y por ello recibe interna y sacramentalmente dichos oficios. En la oración consecratoria hallamos una referencia directa y clara al Spiritus principalis. Existe un carisma que se transmite y se expresa en el hecho de ser pastor, que representa a Jesús, Pastor y servidor de la Iglesia y de la humanidad. Al actuar como «vicario de Cristo», lo hace para enseñar, santificar y regir la grey que se le encomienda, en comunión con el Papa y los demás obispos ${ }^{64}$. Desde este ministerio, cada obispo es «pregonero de la fe y maestro de la Palabra», por lo cual tiene la irrenunciable tarea de anunciar el Evangelio; es el gran liturgo que celebra los misterios de la fe y promueve la santidad de su grey, y con caridad pastoral rige la comunidad eclesial en su peregrinar terreno hacia la plenitud.

63. Cf. S. del Cura Elena, La sacramentalidad, 57-58. «La sacramentalidad del episcopado y el conferimiento sacramental de los tria munera aparecen en los textos de LG como dos afirmaciones estrechamente relacionadas entre sí; de tal modo que la determinación jurídica intervendría no sobre la potestad sacramentalmente radicada, sino en el ejercicio de la misma» (ibid., 61).

64. Para profundizar mejor en esto, se puede leer: R. Blázquez, La ordenación episcopal como lugar teológico, en Facultad de Teología del Norte de España, Teología del sacerdocio. El Ministerio episcopal XXIV, Burgos 2001, 153-174. 
El Concilio Vaticano II presenta una imagen de obispo muy diversa y contraria a lo que durante siglos se mostró: el obispo príncipe, funcionario, «notable social», político... Para ello, apela al icono del Buen Pastor. «La referencia decisiva a Cristo como Buen Pastor hace que la 'caridad pastoral' especifique el ejercicio de las diversas funciones, la entrega de sí por parte del obispo en cuanto primero entre los siervos de Dios y su testimonio del Evangelio para su esperanza del mundo» ${ }^{65}$. Esta presentación supone que el obispo, al actuar como pastor, lo hace como servidor (ministro). Ambas realidades tienen, por la ordenación, un origen carismático: ser pastor y servidor forman parte de la esencia y existencia del obispo. Desde este horizonte, el obispo preside la forma originaria y constitutiva de «eclesialidad» que es la Iglesia particular o local ${ }^{66}$.

\section{e) Vinculación a una Iglesia local}

Este tema está mejor explicitado en Christus Dominus, especialmente en el n. 11. Cada obispo está vinculado a una Iglesia local (incluso quienes tienen algún cargo peculiar, como los obispos auxiliares o quienes realizan un encargo para la Iglesia universal, están "vinculados» a una Iglesia titular que existió en la antigüedad), pero siempre en comunión con el Obispo de Roma y con los obispos de toda la Iglesia: «Cada uno de los obispos, a los que se les ha confiado el cuidado de una Iglesia particular, apacienta sus ovejas como su pastor propio, ordinario e inmediato en el nombre del Señor, bajo la autoridad del Sumo Pontífice, ejerciendo en ella su ministerio de enseñar, santificar y de regir» (n. 11).

Incluso la definición de "Diócesis» muestra una estrecha vinculación con el obispo: «La Diócesis es una porción del Pueblo de Dios, que se confía a un obispo para que la apaciente con la cooperación del presbiterio, de forma que, unida a su pastor y reunida por él en el Espíritu Santo por el Evangelio y la Eucaristía, constituye una Iglesia particular, en la cual verdaderamente está y actúa la Iglesia de Cristo, que es Una, Santa, Católica y Apostólica» (n. 11). En Ad gentes, 19, se habla de la labor y misión que van recibiendo cuando al obispo se le encarga crear una Diócesis: es «la obra de plantación de la Iglesia». Como pastores, «los obispos deben dedicarse a su labor apostólica como testigos de Cristo ante los hombres, no sólo interesándose por los que ya siguen al Príncipe de los Pastores, sino consagrándose totalmente a los que de cualquier modo perdieron el camino de la verdad o desconocen el Evangelio o la misericordia salvadora de Cristo, hasta que todos caminen en toda bondad, justicia y verdad» (ChD 11).

Un elemento importante e irrenunciable de la vinculación del obispo con su Iglesia es el presbiterio. Este no es algo accesorio, sino esencial en y para cada Iglesia local. Hay una vinculación con los presbíteros, pues «aunque no tienen la

65. S. del Cura Elena, Episcopado, 247.

66. Sobre esto se puede ver: J. Villar, Ministerio episcopal y laicado, en Facultad de Teología del Norte de España, Teología del Sacerdocio. El Ministerio episcopal XXIV, 203s. 
cumbre del pontificado y en el ejercicio de su potestad dependen de los obispos, con todo están unidos a ellos por el honor del sacerdocio» (LG 28). El Concilio, desde su eclesiología de comunión, da un paso interesante: «Los presbíteros, próvidos cooperadores del orden episcopal, ayuda e instrumento suyo, llamados para servir al Pueblo de Dios, forman, junto con su obispo, un presbiterio dedicado a diversas ocupaciones» (LG 28). También en Ad gentes, 19, cuando se habla de las nuevas Iglesias que se van creando, se hace mención directa del Obispo y su Presbiterio.

Los presbíteros cooperan y representan al obispo en las diversas comunidades. Bajo la autoridad del mismo y en comunión con él, proclaman el Evangelio, santifican y rigen la porción de la grey a ellos confiada. Debe darse, por tanto, una estrecha comunión de los presbíteros con el obispo, quien debe considerarlos como hijos y amigos. El texto nos presenta una novedad que hace poco ha sido tomada en cuenta en las reflexiones teológicas: «Todos los sacerdotes, tanto diocesanos como religiosos, por razón del Orden y del ministerio, están, pues, adscritos al Cuerpo episcopal y sirven al bien de toda la Iglesia según la vocación y la gracia de cada cual» (LG 28). Esta misma idea es retomada en Presbyterorum ordinis, 7: «Todos los presbíteros, juntamente con los obispos, de tal modo participan del único sacerdocio y del único ministerio de Cristo que la misma unidad de consagración y misión está reclamando su comunión jerárquica con el Orden de los obispos».

En el rito de ordenación, al recibir el anillo episcopal se significa esa estrecha vinculación, de sentido esponsalicio, con la Iglesia local. En ese momento, se reafirma tanto la comunión con sus feligreses como con los demás obispos de la Iglesia. El obispo es consagrado en la verdad para enseñar, santificar y regir su grey. «La permanencia en el Evangelio de la verdad es atestiguado por la Iglesia local en comunión con las demás Iglesias, y en fidelidad a la tradición. El obispo es también hijo y miembro de la Iglesia, como todo cristiano, que en virtud del 'Spiritus principalis' recibido en la ordenación episcopal se convierte en 'padre' y 'testigo autorizado', garante y 'juez de la paz' ${ }^{67}$. El obispo, por su ministerio y consagración, tiene, pues, un lugar particularmente definido en la Iglesia: cabeza de su Iglesia. «El contenido de esta 'capitalidad' en la Iglesia es la 'episcopalis operatio et functio', que consiste en presidir y regular la comunidad cristiana como tal. No ya cualquier forma de agregación en la Iglesia, sino aquella característica de Iglesia, es decir, la eclesialidad fundada precisamente en la interrelación básica del sacerdocio ministerial y del sacerdocio común» ${ }^{68}$.

Por la consagración sacramental, el obispo se vincula a su Iglesia. Lo hace como pastor de la misma y se convierte en el gran instrumento de Dios para su crecimiento y fortalecimiento. Por eso, se da una vinculación estrecha, que

67. R. Blázquez, La ordenación episcopal, 165

68. J. Villar, Ministerio episcopal, 201. 
nos permite decir que el obispo es el gran animador de la vida de la Iglesia. «La convocación-congregación que es la Iglesia se realiza a través de la autoridad de cada obispo que sacramentalmente (Bautismo-Confirmación y Eucaristía) constituye en Iglesia a los que han creído en Cristo. Pertenece, por tanto, a la esencia teológica de la Iglesia particular su presidencia episcopal. Sólo la plenitud sacramental de la sucesión apostólica pueden hacer que una portio sea Populi Dei» ${ }^{69}$. Esto se comprende desde la perspectiva de Iglesia-sacramento. «Los obispos ejercen un ministerio sacramental inserto 'en' la sacramentalidad de la Iglesia, como manifestación particular de la inserción de todos los ministerios en el interior de un Pueblo de bautizados (cf. PO 9), para su edificación y su sustento. Pero la inclusión es mutua, pues, según la fórmula de san Cipriano recogida por Lumen gentium 23 , 'el obispo está en la Iglesia y la Iglesia en el obispo', el obispo 'representa' a su Iglesia en razón del lazo sacramental que los vincula estrechamente» ${ }^{70}$. Así pues, los obispos son los que promueven y mantienen la comunión con la Iglesia universal dentro de la comunión de la Iglesia local. Para ello, se requiere «la capitalidad del obispo, principio y fundamento visible de la unidad en su Iglesia. La presidencia del obispo es un servicio dotado ciertamente de potestad, por no un principio arbitrario, sino que se orienta a potenciar la comunión de todos» ${ }^{71}$.

¿Qué sucede con los obispos que no tienen el encargo de una diócesis? Villar nos advierte lo siguiente: «La Iglesia ha discernido otros ministerios episcopales iure ecclesiastico que no sustituyen el originario, ni son alternativos a la presidencia de una Iglesia local $»^{72}$. Hay obispos que tienen un ministerio dirigido a una Iglesia local: Ordinarios Militares, Ordinarios rituales, Prelados personales, Obispos auxiliares y Obispos «titulares» con un ministerio relacionado con el ejercicio de la autoridad suprema papal para la Iglesia universal ${ }^{73}$. En esta misma línea entran los obispos eméritos. «El obispo emérito permanece con pleno título miembro del Colegio episcopal, al cual pertenece por la fuerza de la consagración episcopal y de la comunión jerárquica con el Romano Pontífice y sus hermanos obispos (...). En cuanto es miembro del Colegio, el obispo emérito tiene el derecho y el deber de asistir al Papa en el gobierno de la Iglesia universal» $»^{74}$.

69. Ibid., 203.

70. S. del Cura Elena, Episcopado, 243. También se puede y debe ver esto con la vinculación a la misión de la Iglesia. «Por ello, los obispos son, en cuanto poseedores de la sacri ministerii summa, los primeros servidores de una salvación y de un dinamismo misionero» (ibid.).

71. J. Villar, Ministerio episcopal, 213.

72. Ibid., 207.

73. Cf. Ibid. «Teológicamente nada impide un desarrollo de la episkopé universal en un servicio 'formalmente' diverso de la convocación in recto de una Iglesia local, y que se realizará 'materialmente' en las Iglesias locales (de muchas o de pocas) bajo la presidencia de sus pastores (según determinaciones canónicas); o bien ministerios en el ámbito de la episkopé del sucesor de Pedro para la comunión de las Iglesias (Curia romana, etc.)». Ibid., 209.

74. Congregación para los Obispos, El Obispo emérito, Roma 2008. 
Un elemento que no se debe olvidar es el de la estrecha relación entre cada obispo y su Presbiterio. Esta hay que considerarle desde dos ángulos: el de la teología del orden sacerdotal (presbiterado y episcopado) y el eclesiológico (obispo-presbiterio). Ambas son necesarias y se exigen mutuamente.

El Concilio Vaticano II realiza un cambio copernicano en la presentación de la teología del orden sacerdotal. Esto se debe, entre otras cosas, a la concepción del ministerio episcopal y a la acentuación de la participación de todos los bautizados en la misión de la Iglesia. El reconocimiento de la sacramentalidad del episcopado permite delinear la teología y sacramentalidad del presbiterado. Ambos (junto con el diaconado) son grados del Orden; y apuntan no sólo a la celebración de la Eucaristía y los otros sacramentos, sino también a la Misión de la Iglesia y a la edificación de la comunidad eclesial. No se trata de una mera subordinación de los presbíteros ante el obispo, sino una participación en el único sacerdocio de Cristo. Los obispos reciben la plenitud del sacerdocio, que no significa fuente del presbiterado, «pues el presbítero participa del sacerdocio de Cristo y la dependencia respecto al obispo lo es en el 'ejercicio' pastoral de las potestades ministeriales» ${ }^{75}$.

Lo que permitirá abrir espacios de comprensión a la relación entre el episcopado y el presbiterado es lo que podemos considerar como la perspectiva eclesiológica de esa mutua relación; es decir, la comunión del obispo con sus presbíteros (presbiterio). Éstos, en el Concilio Vaticano II, son considerados «próvidos cooperadores» del obispo (LG 28). «Esto no significa que haya insubordinación o autonomía radical. Existe una relación de subordinación en la obediencia, pero vista desde la participación en el sacerdocio de Cristo y desde el prisma de la comunión. Entre el obispo y los presbíteros se da, pues, una estrecha comunión que definirá el presbiterio» ${ }^{76}$.

Esa íntima vinculación se da en la Iglesia local y «es un vínculo de comunión orgánico sacramental» ${ }^{77}$. Esta comunión se manifiesta en el presbiterio que es una realidad que marca y define la unidad en la Iglesia local. Es una comunión de carácter teológico. El obispo no puede prescindir de su presbiterio para pastorear, y viceversa, el presbiterio requiere estar unido a su obispo para pastorear ${ }^{78}$. «El obispo es ministro de la comunión en su Iglesia local y esto se da de manera especial con el presbiterio con cuyos miembros se tiene que dar una comunión afectiva y efectiva. El obispo debe prestar atención a cada uno de sus presbíteros, lo cual constituye una obligación y una responsabilidad; a la vez, debe cultivar la comunicación y comunión con todos los presbíteros. Esta labor

75. S. del Cura Elena, La sacramentalida, 71. «No obstante, queda la impresión de que la diferenciación sacramental entre obispo y presbítero no se ha esclarecido suficientemente y que la relación entre ambos no ha encontrado articulación eclesiológica convincente». Ibid.

76. M. Moronta, El Presbiterio y la Fraternidad Sacramental, Madrid 2008, 61-62.

77. Ibid., 62.

78. Cf. Ibid., 63. 
es fruto de la caridad pastoral del mismo obispo, la cual apunta a un trabajo de comunión de los obispos con los presbíteros y de éstos con sus hermanos de presbiterio (cf. PDV 23d)» 79 .

Todo lo antes señalado nos permite concluir que el ministerio del obispo que se realiza en su Iglesia local, junto con su presbiterio, le permite actuar como «hacedor» de la comunión y como responsable de la misión recibida. Para ello, cual sucesor de los Apóstoles y dentro del Colegio episcopal, goza de la fuerza sacramental que le da la ordenación o consagración episcopal para actuar en nombre de Jesucristo, como sumo Pontífice en su Iglesia local.

\section{Elementos para una Teología Conciliar del Episcopado}

La elaboración de una teología del episcopado, con especial énfasis y punto de referencia al Vaticano II, es una tarea aún pendiente. Después del Concilio, se ha tenido un enriquecimiento con algunos documentos del magisterio eclesial ${ }^{80}$. Para dicha tarea es preciso tener en cuenta algunos elementos que hemos podido avizorar en la síntesis hasta ahora desarrollada. Los mencionamos de manera sucinta, como un aporte y sugerencia para el lector, con el deseo de que en un futuro cercano se pueda hacer una teología más desarrollada y completa acerca del episcopado. Esta, a su vez, no se puede hacer aisladamente sin referencia a la eclesiología y a la teología del sacramento del orden.

El episcopado es un grado del Orden sacerdotal y hay que verlo y asumirlo como expresión sacramental del sacerdocio. Para ello, se requiere tener muy en cuenta la relación con el presbiterado en todas sus dimensiones. Al verlo, desde esta perspectiva hay que encuadrarlo ante todo en la cristología: sencillamente desde su razón de ser, el sacerdocio de Jesús, el Señor. Esto nos conducirá necesariamente a otro horizonte, consecuencia de la acción salvífica del Sumo y Eterno Sacerdote, cual es la incorporación, por el bautismo, de todos los cristianos en el sacerdocio común de los fieles. De entre ellos, son llamados quienes van a ser consagrados para ejercer, en su beneficio, el ministerio sacerdotal con sus funciones de enseñanza, santificación y pastoreo. Es algo que pueden y deben realizar dentro del único pueblo sacerdotal, que es la Iglesia.

Aquí nos encontramos con el horizonte eclesiológico. Se es sacerdote y, por tanto, obispo, dentro del Pueblo de Dios y al servicio del mismo. La eclesiología

79. Ibid., 68-69. «En la realización de esta labor de unidad, el obispo debe ser para sus presbíteros el padre, el amigo y el hermano que aúne a cada uno con los que está unido afectiva y efectivamente, pero, ante todo, de manera sacramental. Desde este horizonte es como se logrará entender el cómo y el por qué de la relación 'comunional' del obispo con su presbiterio, que, a la vez, se contagiará dentro del mismo como realidad también sacramental de comunión y fraternidad». Ibid., 69.

80. Sagrada Congregación los Obispos, Ecclesia Imago, Roma 1973; Congregación para los Obispos, Apostolorum Successores, Roma 2004; Juan Pablo II, Exhortación Apostólica «Pastores gregis», Roma 2003; Congregación para los Obispos, El Obispo emérito, Roma 2008. 
de comunión, peculiar del Vaticano II, marcará esa reflexión teológica. Además de su fundamento trinitario, el episcopado es un ministerio de la Iglesia-comunión. Precisamente es signo (sacramento) de esa comunión que edifica y sostiene en su Iglesia local, y es testigo de la misma por su pertenencia al colegio episcopal y en comunión plena con el sucesor de Pedro. Junto con su presbiterio, el obispo hace la comunión de la Iglesia local. Al hacerlo, por la dinámica de la ministerialidad de la Iglesia, promueve la participación de todos en la misión recibida de Jesucristo. Por eso, toda reflexión teológica sobre el episcopado debe hacer referencia a esa misión, en la que los obispos participan como sucesores de los Apóstoles.

En todo esto hay que tener muy presente el reconocimiento que el Concilio Vaticano Il hace de la sacramentalidad del episcopado. Es una verdad teológica, con la que se dilucida el panorama histórico y se aclara la teología del episcopado. Es una de las propuestas avanzadas del Concilio. La presentación de la Iglesia como «sacramento de comunión y salvación» va a influir notablemente también en la reflexión sobre la sacramentalidad del obispo. «Los obispos ejercen un ministerio sacramental inserto en la sacramentalidad de la Iglesia, como manifestación de todos ministerios en el interior de un Pueblo de bautizados (cf. PO 9)» ${ }^{81}$.

Con estos elementos, ciertamente, se podrá hacer una síntesis teológica acerca del episcopado, la cual, a la vez, hay que insertarla en la visión global del sacramento del orden y de la eclesiología de comunión.

\section{A MODO DE CONCLUSIÓN}

Las páginas precedentes encierran un modesto aporte para una visión teológica del episcopado en el marco del Concilio Vaticano II. Se ha pretendido pasar una rápida revista sobre algunos datos históricos pre-conciliares y elaborar una síntesis de lo que el Concilio trató acerca del episcopado. Éste fue uno de los temas clave en su eclesiología. El Concilio dio un paso importante al tratar sobre la sacramentalidad del episcopado; sacramentalidad que influye en los oficios propios del ministerio episcopal y en la pertenencia al Colegio de los obispos. Sacramentalidad que le viene transmitida en la sucesión apostólica con la cual llegamos a la raíz y fuente, que es Cristo. Sacramentalidad que se nutre de lo que distingue también a la Iglesia, «sacramento universal de comunión y salvación».

Esta conclusión quiere abrirse también a otra tarea necesaria y que, además debe enmarcarse en la Teología del episcopado: delinear la identidad propia del obispo. Tanto el Vaticano II como el magisterio posterior brindan puntos concre-

81. S. del Cura Elena, La sacramentalidad, 17. «La sacramentalidad de la Iglesia significa que lo visible en ella constituye el signo de fiesta y presencializador (símbolo real) de la salvación de Dios en Cristo para el mundo entero». Ibid., 46. 
tos para ello. De manera especial hacemos mención de Pastores gregis, fruto de lo que se reflexionó durante la Asamblea general del Sínodo sobre el obispo, hermosamente redactada por Juan Pablo II. Esta exhortación nos ofrece las líneas para dibujar la identidad del obispo: con ella, además de reconocer el ser teológico del obispo, podemos ver cuál es el quehacer pastoral y ministerial, para así llegar a asumir la espiritualidad que identifica al obispo. Esperamos que más de un lector pueda dar este paso.

Gracias al Vaticano II, cuyo primer cincuentenario conmemoramos, podemos tener las bases para una teología del episcopado y para una reflexión sobre la identidad del obispo. El Concilio fue realista y fue, además, un ejercicio de confianza en el Señor; en esta línea, sin romper con la auténtica Tradición eclesial y sin dejar de mirar al futuro, fue sentando las bases para que la Iglesia pudiera dialogar con el mundo en medio del cual realiza su misión de anunciar el Evangelio y de edificar el Reino. Con una eclesiología de comunión y el énfasis en la participación de todos los miembros del pueblo sacerdotal en esa misión, en sus documentos, "considerando también las condiciones de la sociedad humana, que en nuestra época está encaminada hacia un orden nuevo [trató] de determinar más concretamente el ministerio pastoral de los obispos» (ChD 3). 